\section{Management of paediatric recurrent urinary tract infections and challenges in special patient populations}

CPD

Clara T Petcu, Emma Stehr,

James P Isaac, Devang Desai

\section{Background}

Urinary tract infections (UTIs) affect up to $8.4 \%$ of girls and $1.7 \%$ of boys within their first six years of life. The rate of recurrence is as high as $30 \%$, with the effects carrying long-term morbidity. Concomitant pathology such as vesicoureteric reflux (VUR) or bowel and bladder dysfunction (BBD) can pose further diagnostic and management challenges in the primary care setting.

\section{Objective}

The aim of this article is to discuss the approach to diagnosis and management of recurrence and strategies to prevent it, with additional information regarding patients with VUR and BBD.

\section{Discussion}

Management of recurrent UTIs requires family-centred care, with conservative, pharmacological and surgical options effective across different patient groups. In situations that exceed the capacity of local services, referral to paediatric subspecialties should be considered to assist in further investigation of recurrent cystitis-like symptoms.
RECURRENT URINARY TRACT INFECTIONS (rUTIs) are a clinical challenge for all involved in the care of the paediatric patient, with $8.4 \%$ of girls and $1.7 \%$ of boys diagnosed with a urinary tract infection (UTI) within the first six years of life. ${ }^{1}$ Up to $30 \%$ of these children will experience at least one recurrence within 6-12 months. ${ }^{2,3}$ While $3-15 \%$ of children with a first UTI will show renal parenchymal scarring within 1-2 years of their first UTI, ${ }^{4-7}$ the risk of acquired chronic kidney disease remains low. ${ }^{5,8}$

An rUTI can be defined as a repeated presentation with separate episodes of cystitis, pyelonephritis or urosepsis.

Vesicoureteric reflux (VUR) is one of a myriad of structural abnormalities that may increase the risk of rUTIs, affecting up to $40 \%$ of children who have had a UTI. ${ }^{9}$ It is important to recognise that in a third of paediatric patients, a UTI can be the initial symptom of urinary tract anatomical variation or other concomitant pathology. ${ }^{3}$

Understanding the cause of rUTIs is crucial for determining whether a conservative or invasive approach is most appropriate. $^{10}$

The scope of this article is to review the various causes of rUTIs and management strategies ranging from conservative to surgical, with the aim of increasing clinician confidence in the primary care setting. There will also be an emphasis on

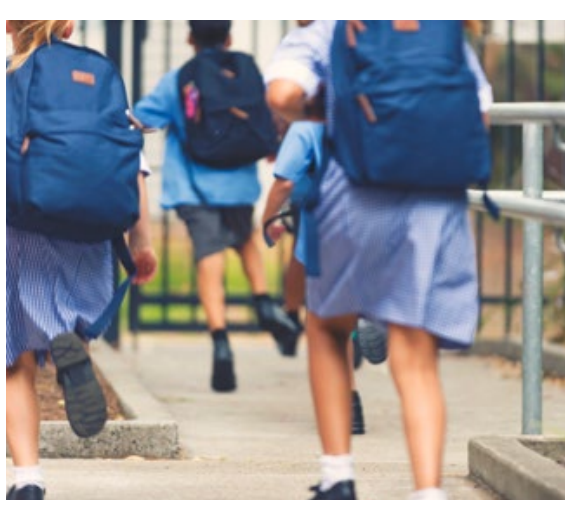

VUR and bowel and bladder dysfunction (BBD) as they relate specifically to rUTIs.

\section{Pathogenesis of recurrent urinary tract infections}

UTIs are secondary to ascending periurethral colonisation from uropathogens, with Escherichia coli accounting for over $75 \%$ of cases. Other bacteria such as Proteus spp., Klebsiella spp., Enterobacter spp., Enterococcus spp., Citrobacter spp. or Staphylococcus aureus may also be causative agents. Less commonly, fungal infections (eg candidiasis) and viral pathogens (eg adenovirus, BK virus) may be involved. ${ }^{10}$

These pathogens may cause lower tract disease (eg cystitis, prostatitis), upper tract illness (pyelonephritis, abscess) or systemic illness (urosepsis). UTIs can thus be classified by anatomical position, severity, symptoms or episode.

\section{Diagnosis of recurrent urinary tract infections}

Diagnosis of UTI in children is guided by a targeted history and examination, with investigations especially important in infants and non-verbal patients in order to exclude other differentials (Table 1). ${ }^{11,12}$

Dysuria, urgency, frequency, abdominal/flank pain or incontinence 
can be reported by verbal children or their carers. As a result of non-specific presentations of fever and general distress in infants, it is important to consider UTI as part of the differential diagnosis. ${ }^{5,13}$
A febrile infant younger than three months of age should be promptly managed in accordance with local guidelines, ${ }^{14}$ which in certain circumstances may recommend

\begin{tabular}{ll}
\hline Table 1. Differential diagnoses for urinary tract infection ${ }^{11,12}$ \\
\hline Differential diagnosis & Associated clinical features \\
\hline Vaginitis & $\begin{array}{l}\text { Vaginal discharge, odour, pruritus. There is no frequency } \\
\text { or urgency. }\end{array}$ \\
\hline Vulvovaginitis & Can cause dysuria and may co-exist with UTIs. \\
\hline Urethritis & Urinalysis shows pyuria but no bacteria. \\
\hline Urge syndrome & $\begin{array}{l}\text { Frequency of micturition, urgency, daytime wetting and } \\
\text { nocturnal enuresis. }\end{array}$ \\
\hline Painful bladder syndrome & Dysuria, frequency, urgency without evidence of infection. \\
\hline Pelvic inflammatory disorder & $\begin{array}{l}\text { Lower abdominal/pelvic pain, fever, cervical discharge and } \\
\text { cervical motion tenderness. }\end{array}$ \\
\hline Prostatitis & $\begin{array}{l}\text { Tender prostate and pain on ejaculation. May be associated } \\
\text { with or as a result of a concurrent UTI. }\end{array}$ \\
\hline Sepsis or bacteraemia & $\begin{array}{l}\text { Fever, malaise, anorexia, lethargy. Non-verbal children and } \\
\text { infants may present with similar symptoms for UTI as for } \\
\text { sepsis. Early recognition and treatment of sepsis is critical. }\end{array}$ \\
\hline UTI, urinary tract infection & \\
\hline
\end{tabular}

management on the basis of clinical suspicion without awaiting confirmatory testing.

A range of options exist for the collection of a urine specimen from a child (Table 2). It is important to consider not only the quickest or simplest collection method, but also one that will yield the cleanest sample free of contaminants. ${ }^{5,13}$

To diagnose a UTI, suspicion of infection must be clinically correlated to both of the following criteria: ${ }^{13}$

- urinalysis suggesting pyuria and/or bacteriuria

- a urine culture of a uropathogen with at least 50,000 colony-forming units (CFUs) per millilitre.

Urine specimen collection should therefore be performed during each episode where there is clinical suspicion of a UTI, or intent to treat it as such.

An rUTI in children is diagnosed on the basis of the following criteria: ${ }^{15}$

- two or more episodes of acute pyelonephritis

- one episode of acute pyelonephritis and one episode of cystitis

- three or more episodes of cystitis.

Table 2. Options for the collection of urine specimens from paediatric patients, $5,10,13,37$

\begin{tabular}{|c|c|c|c|}
\hline & Clean catch/midstream urine & Urethral catheterisation & Suprapubic aspiration \\
\hline \multirow[t]{2}{*}{ Procedure } & $\begin{array}{l}\text { Midstream urine caught in a clean } \\
\text { specimen pot. }\end{array}$ & $\begin{array}{l}\text { Collection of urine via 'in and out' } \\
\text { catheterisation. }\end{array}$ & $\begin{array}{l}\text { Collection of urine via ultrasound- } \\
\text { guided needle aspiration. }\end{array}$ \\
\hline & $\begin{array}{l}\text { In infants or non-verbal children, } \\
\text { stimulation of the cutaneous voiding reflex } \\
\text { by wiping the perigenital area with a cold, } \\
\text { damp gauze may also be used to achieve } \\
\text { a sample. }\end{array}$ & $\begin{array}{l}\text { Thorough cleaning and aseptic non- } \\
\text { touch technique must be used to } \\
\text { minimise contamination and reduce } \\
\text { risk of subsequent infection. }\end{array}$ & $\begin{array}{l}\text { Must be performed with a full bladder } \\
(>20 \mathrm{~mL}) \text {, with the child on their back } \\
\text { and restrained by the caregiver. } \\
\text { Light sedation may be required. }\end{array}$ \\
\hline \multirow[t]{4}{*}{ Indication } & Continent or older children able to follow & Infants and pre-continent children. & Infants. \\
\hline & $\begin{array}{l}\text { instructions and indicate when they are } \\
\text { experiencing urinary urge. }\end{array}$ & $\begin{array}{l}\text { Children unable to provide a clean } \\
\text { catch sample. }\end{array}$ & $\begin{array}{l}\text { Uncircumcised boys where adequate } \\
\text { foreskin retraction is not possible. }\end{array}$ \\
\hline & First-line non-invasive measure in pre- & Acute urinary retention. & Girls with labial adhesions. \\
\hline & $\begin{array}{l}\text { continent children and infants where there } \\
\text { is good parental cooperation and rapport. }\end{array}$ & & Cases of periurethral irritation. \\
\hline \multirow[t]{4}{*}{ Benefits } & Non-invasive. & May be less painful and invasive & Preferred method of aseptic collection. \\
\hline & Minimal contamination. & than suprapubic aspiration. & With appropriate technique, provides a \\
\hline & & Effective in urinary retention. & sample with minimal contamination. \\
\hline & & & $\begin{array}{l}\text { Relatively quick procedure provided } \\
\text { patient has a full bladder. }\end{array}$ \\
\hline \multirow[t]{3}{*}{ Disadvantages } & Reliant on child and caregiver cooperation. & Invasive and poorly tolerated. & Invasive and painful. \\
\hline & May be time-consuming. & $\begin{array}{l}\text { Risk of iatrogenic introduction of } \\
\text { uropathogens. }\end{array}$ & $\begin{array}{l}\text { May be poorly tolerated by older } \\
\text { children or caregivers. }\end{array}$ \\
\hline & & & May require sedation. \\
\hline
\end{tabular}


The range of predisposing factors associated with rUTIs is illustrated in Table $3 .^{10,12,13,16}$

\section{Management of recurrent urinary tract infections}

Successful management of rUTIs requires collaboration between the children, caretakers and healthcare professionals. ${ }^{17}$ Referral to a paediatric service for review should be considered where appropriate. Education should be provided to carers such that in future febrile illnesses, prompt medical evaluation should occur to ensure that rUTIs are managed in a timely manner. ${ }^{13}$

\section{Acute management}

Following investigation, appropriate choice of antibiotics should be made on the basis of local sensitivities, guidelines and growth sensitivities in previous UTIs. ${ }^{18-20}$ The decision for oral administration of antibiotics should consider the patient's age, risk of urosepsis, compliance with oral management, and other clinical factors (vomiting, diarrhoea). ${ }^{21,22}$ Where necessary, parenteral therapy should be given. Repeat imaging and monitoring of renal function should be considered, especially in those with rUTIs.

\section{Referral}

Referral to the local tertiary service for consultation should be contemplated in children aged $<6$ months, children with evidence of sepsis or shock, and those who require care beyond the capacity of their local services..$^{22,23}$ Based on local service availability and guidelines, referral can be to a paediatrician, paediatric urologist or, in some cases, the local urology service.

\section{Prevention}

\section{Hygiene practices}

Children and caregivers should be educated on hygiene practices that minimise bacterial burden. ${ }^{18}$ Education on perineal care including wiping (dabbing or front-toback) post-bowel motions ${ }^{23}$ and appropriate washing of the glans and foreskin in uncircumcised boys may assist in prevention of uropathogen colonisation. ${ }^{18}$

Avoidance of bubble baths, which can cause mucosal irritation and genital discomfort, is recommended to decrease mimics of an impending UTI. ${ }^{5}$

Parents can refer to several resources when learning about good hygiene practices for children, namely Raising Children Network (https://raisingchildren. net.au $)^{24}$ and The Royal Children's Hospital Melbourne (RCH), which provide information regarding penis and foreskin care. ${ }^{25}$ The $\mathrm{RCH}$ also provides information regarding vulval skin care for both children ${ }^{26}$ and adolescents. ${ }^{27}$

Conservative (non-antibiotic) prevention Probiotics have garnered much attention in their possible role to prevent rUTIs, despite little current evidence to suggest usage. ${ }^{28-30}$

Cranberry products, although safe, are poorly tolerated and may only confer a benefit in patients with normal anatomy. ${ }^{15,28}$ Research on the topic has been conflicting and often of low quality. ${ }^{31}$

The identification and management of disorders such as VUR and BBD is important for preventing UTIs in these patient groups, and further detailed later in this article.

\section{Antibiotic prevention of recurrent urinary tract infections}

Extensive studies into the role of antimicrobial prophylaxis of UTIs have shown no evidence to suggest initiation from the index UTI. Given the likelihood of developing resistance, it is recommended that a paediatric specialist be involved in the decision to initiate long-term antibiotic prophylaxis. Additionally, continuous antibiotic prophylaxis (CAP) therapy is associated with adverse effects in $8-10 \%$ of cases, with most being non-serious reactions including nausea, vomiting and skin reactions. ${ }^{32}$

Overall, CAP should be considered in high-risk populations that are susceptible to rUTIs and at risk of renal damage. ${ }^{5,21}$ Patients with both VUR and BBD are at the highest risk of $\mathrm{rUTI}^{5,33}$ and may benefit most from CAP. ${ }^{34}$ The antimicrobial options for CAP are included in Table $4 . .^{35,36}$

Table 3. Factors that increase risk of urinary tract infections ${ }^{10,12,13,16}$

\begin{tabular}{|c|c|c|c|c|}
\hline Virulence factors & Concurrent illness & $\begin{array}{l}\text { Anatomical, causing } \\
\text { stasis of urine }\end{array}$ & Functional & Behavioural \\
\hline $\begin{array}{l}\text { - Resistance in } \\
\text { uropathogens } \\
\text { - Incomplete or } \\
\text { inappropriate } \\
\text { treatment of prior } \\
\text { episodes } \\
\text { - Immunosuppressed } \\
\text { host } \\
\text { - Colonisation of } \\
\text { indwelling catheter }\end{array}$ & $\begin{array}{l}\text { - Gastroenteritis or } \\
\text { diarrhoeal illness } \\
\text { increasing periurethral } \\
\text { spread of coliforms } \\
\text { - Dehydration leading } \\
\text { to reduced voiding } \\
\text { frequency and } \\
\text { increased stasis } \\
\text { - Vaginitis or } \\
\text { vulvovaginitis } \\
\text { - Candidiasis (genital } \\
\text { thrush) } \\
\text { - Concurrent } \\
\text { bacteraemia }\end{array}$ & $\begin{array}{l}\text { - Vesicoureteric reflux } \\
\text { (primary or secondary) } \\
\text { - Posterior urethral valves } \\
\text { - Phimosis } \\
\text { - Other obstructive } \\
\text { uropathy (any level), } \\
\text { including urolithiasis } \\
\text { - Congenital } \\
\text { abnormalities of the } \\
\text { kidney and ureteric } \\
\text { tract }\end{array}$ & $\begin{array}{l}\text { - Bowel and bladder } \\
\text { dysfunction including } \\
\text { constipation } \\
\text { - Other neurogenic } \\
\text { bladder causes }\end{array}$ & $\begin{array}{l}\text { - Sexual intercourse } \\
\text { - Encopresis } \\
\text { - Periurethral colonisation } \\
\text { secondary to poor } \\
\text { hygiene practices }\end{array}$ \\
\hline
\end{tabular}




\section{Surgical management of recurrent urinary tract infections}

While the majority of rUTIs respond to conservative or pharmacological management, in a small subset of boys with rUTIs, surgical management may be recommended. ${ }^{37-39}$ In uncircumcised boys $<1$ year of age with rUTIs or grades III-V VUR, circumcision can be considered on the basis of the child's baseline risk and foreskin anatomy. ${ }^{28,39}$ In this particular age group, the risk of UTI and rUTI is highest when compared with older children, girls of the same age and uncircumcised infant boys, with studies also suggesting an increased risk of complications and renal scarring following UTI. Thus, circumcision is weighed against non-invasive measures, with a greater benefit in infants aged $<1$ year. ${ }^{38}$ The decision to proceed to circumcision should be accompanied by a thorough discussion between parents, the primary care physician and specialist services. ${ }^{39}$

\section{Recurrent urinary tract infections in high-risk patient populations \\ Vesicoureteric reflux \\ Definition}

VUR is a common anatomical anomaly in children. ${ }^{21}$ It is often diagnosed following investigation of a UTI, as approximately
$30 \%$ of children with UTIs will be diagnosed with VUR. ${ }^{40}$ Recurrence will affect $20-30 \%$ of children diagnosed with VUR. ${ }^{40}$

VUR is the retrograde flow of urine from the bladder to the kidney due to a dysfunctional vesicoureteric junction (VUJ).$^{41}$ It can be both an anatomical and functional disorder, influenced by anatomical changes in the intramural ureter, ureteric opening width and function of trigone and ureteric muscles. ${ }^{40}$ VUR is associated with developing renal scarring, renal hypertension or chronic end-stage kidney disease. ${ }^{17}$

Table 4. Agents used in continuous antibiotic prophylaxis ${ }^{35,36}$

\begin{tabular}{|c|c|c|c|}
\hline Antibiotic regimens & $\begin{array}{l}\text { Dosage and } \\
\text { administration }\end{array}$ & Common side effects & Practice notes \\
\hline $\begin{array}{l}\text { Trimethoprim and } \\
\text { sulfamethoxazole } \\
\text { (age >1 month) }\end{array}$ & $\begin{array}{l}\text { - } 2+10 \mathrm{mg} / \mathrm{kg} \mathrm{up} \\
\text { to } 80+400 \mathrm{mg} \\
\text { - Orally } \\
\text { - At night }\end{array}$ & $\begin{array}{l}\text { - Fever } \\
\text { - Gastrointestinal upset: nausea, } \\
\text { vomiting, diarrhoea, anorexia } \\
\text { - Rash or itch } \\
\text { - Sore mouth } \\
\text { - Hyperkalaemia } \\
\text { - Thrombocytopaenia }\end{array}$ & $\begin{array}{l}\text { - Contraindications: preterm infants, infants } \\
\text { <6 weeks of age, megaloblastic anaemia, } \\
\text { HIV, SLE, concurrent treatment with oral } \\
\text { typhoid vaccine, renal impairment, severe } \\
\text { liver disease } \\
\text { - Monitoring required during long-term } \\
\text { therapy: } \\
\text { - Full blood examination } \\
\text { - Folate levels } \\
\text { - Serum potassium }\end{array}$ \\
\hline Trimethoprim & $\begin{array}{l}\text { - } 2 \mathrm{mg} / \mathrm{kg} \text { up } \\
\text { to } 150 \mathrm{mg} \\
\text { - Orally } \\
\text { - At night }\end{array}$ & $\begin{array}{l}\text { - Fever } \\
\text { - Gastrointestinal upset: nausea, vomiting } \\
\text { - Rash or itch } \\
\text { - Hyperkalaemia }\end{array}$ & $\begin{array}{l}\text { - Contraindications: megaloblastic anaemia, } \\
\text { folate deficiency, renal impairment } \\
\text { - Monitoring required during long-term } \\
\text { therapy: } \\
\text { - Full blood examination } \\
\text { - Folate levels } \\
\text { - Serum potassium }\end{array}$ \\
\hline Cefalexin & $\begin{array}{l}\text { - } 12.5 \mathrm{mg} / \mathrm{kg} \text { up } \\
\text { to } 250 \mathrm{mg} \\
\text { - Orally } \\
\text { - At night }\end{array}$ & $\begin{array}{l}\text { - Gastrointestinal upset: nausea, } \\
\text { vomiting, diarrhoea } \\
\text { - Opportunistic infection: Clostridium } \\
\text { difficile, Candidiasis, Enterococcus spp. } \\
\text { - Rash } \\
\text { - Headache } \\
\text { - If injected: pain and inflammation } \\
\text { at the injection site }\end{array}$ & $\begin{array}{l}\text { - Contraindications: severe hypersensitivity } \\
\text { to penicillins or carbapenems may lead to } \\
\text { cross-reactivity } \\
\text { - Monitoring required during long-term } \\
\text { therapy: } \\
\text { - Full blood examination } \\
\text { - Renal function }\end{array}$ \\
\hline $\begin{array}{l}\text { Nitrofurantoin } \\
\text { (age >1 month) }\end{array}$ & $\begin{array}{l}\text { - } 1 \mathrm{mg} / \mathrm{kg} \mathrm{up} \\
\text { to } 50 \mathrm{mg} \\
\text { - Orally } \\
\text { - At night }\end{array}$ & $\begin{array}{l}\text { - Gastrointestinal upset: nausea, } \\
\text { vomiting, diarrhoea, anorexia, } \\
\text { abdominal pain } \\
\text { - Allergic skin reactions } \\
\text { - Headache }\end{array}$ & $\begin{array}{l}\text { - Contraindications: renal impairment } \\
\text { - Monitoring required during long-term } \\
\text { therapy: } \\
\text { - Pulmonary function } \\
\text { - Three-monthly liver function testing } \\
\text { - Renal function }\end{array}$ \\
\hline
\end{tabular}

HIV, human immunodeficiency virus; SLE, systemic lupus erythematosus 
VUR severity is graded on the basis of the height of retrograde flow, dilation and tortuosity of the ureters. ${ }^{40}$ The five different categories of VUR severity are described in Figure 1. ${ }^{21,42}$

\section{Diagnosis}

Investigation of suspected VUR should begin with simple ultrasonography of the kidneys, ureters and bladder (KUB), which will assess the renal parenchyma for scarring or anatomical abnormalities ${ }^{43}$ and may have a role in diagnosing low-grade (I-III) disease. ${ }^{44}$

After completing routine investigations, the child should be referred to a paediatric specialist, who may choose to complete further and more invasive testing. ${ }^{45}$

Voiding cystourethrography (VCUG) is the gold-standard investigation for VUR, indicated in rUTIs, a first febrile UTI and/or an abnormal renal ultrasound. ${ }^{28,46,47}$ A dimercaptosuccinic acid nuclear scan can also be performed to assess renal scar formation as it is considered the gold standard. ${ }^{10}$

Grading of VUR on VCUG is directly linked to decision making regarding treatment in a specialised setting. Understanding of this can be used to support patients and their families/ caregivers (Figure 1).

\section{Management}

Once VUR is confirmed, the approach to management is contingent on the grade of VUR, presence of febrile UTI, age and sex of the patient and presence of bladder or bowel dysfunction. ${ }^{48}$

Management options include surveillance, CAP and various surgical interventions. ${ }^{49}$ Typically, young age (ie $<1$ year) and low-grade VUR (I-III) are favourable for spontaneous resolution and therefore do not require surgical intervention if uncomplicated. ${ }^{21,49}$
There has been significant debate regarding the use of CAP. ${ }^{48}$ The benefit derived is typically dependent on several factors including age, severity of VUR, presence of BBD, toilet training and circumcision status. ${ }^{49}$

In several studies, CAP was found to significantly reduce the number of rUTIs in VUR grade $\geq$ III; however, prevention of renal scarring was not a statistically significant outcome. ${ }^{50,51}$ Studies demonstrate mild support for CAP in low-grade reflux. ${ }^{21}$

Surgical treatment is recommended in patients with high-grade VUR ( $\geq I V)$, ineffective or poorly tolerated CAP or evidence of renal damage. It is the quickest solution for VUR; however, there is no evidence supporting reduced renal scarring. ${ }^{33}$ Options for management include open surgery (gold standard), endoscopic treatment and robot-assisted laparoscopic ureteral implantation. ${ }^{34}$

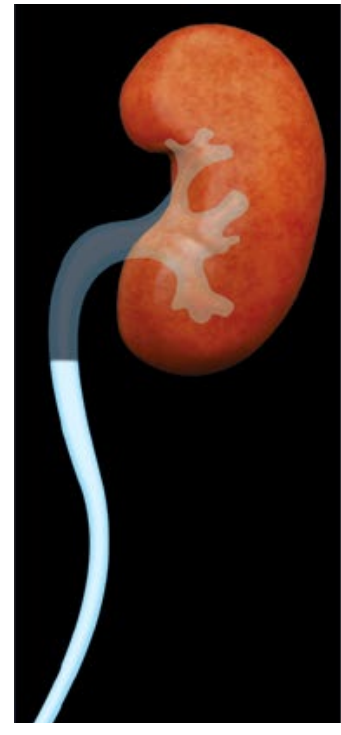

\section{Grade I}

Ureteral dilatation and reflux not affecting the renal pelvis

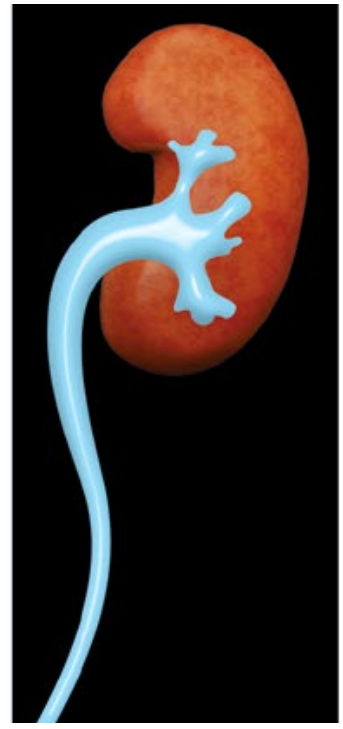

\section{Grade II}

Reflux affecting the renal pelvis, without dilatation of the collecting system; normal fornices

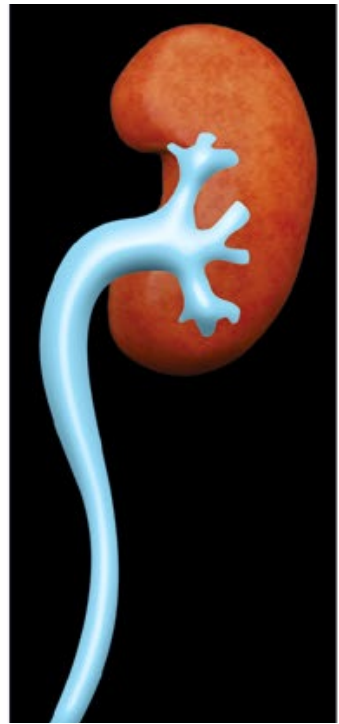

\section{Grade III}

Mild to moderate ureteral and collecting system dilatation; may be with or without kinking. Fornices appear normal, or may be minimally deformed

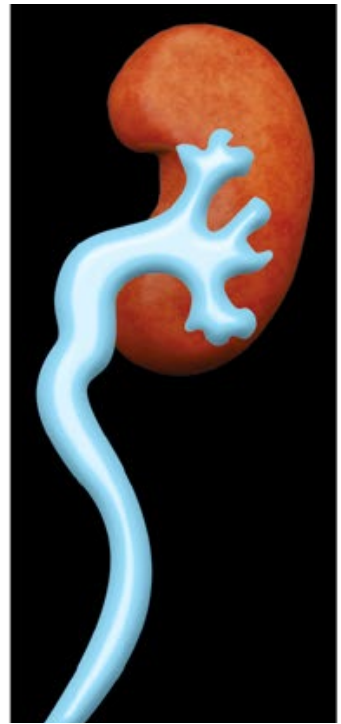

\section{Grade IV}

Moderate ureteral and collecting system dilatation, blunting of fornices. May involve some degree of ureteral kinking. Papillae impressions and architecture still visible

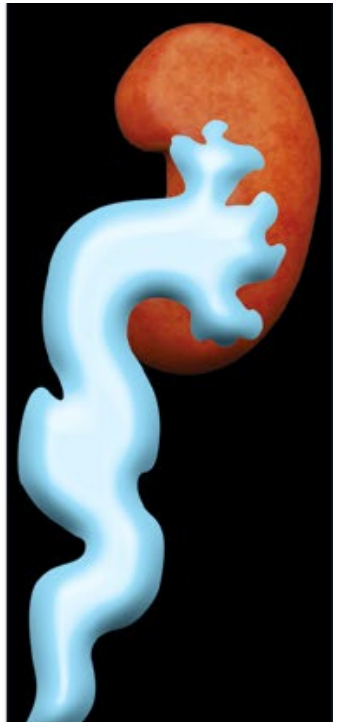

\section{Grade V}

Intraparenchymal reflux with loss of papillary architecture, gross ureteral and collecting system dilatation and ureteral kinking

Figure 1. Appearance of vesicoureteric reflux on voiding cystourethrography ${ }^{21,42}$ 


\section{Bowel and bladder dysfunction Definition}

BBD, previously known as dysfunctional elimination syndrome, is associated with an increased risk of rUTIs. BBD is characterised by a set of lower urinary tract and bowel symptoms such as urgency, withholding manoeuvres, daytime urinary incontinence, constipation and painful defecation..$^{28,52}$ Despite being a risk factor for rUTIs and worsened in the setting of VUR, ${ }^{1}$ $\mathrm{BBD}$ is a common urological paediatric complaint often under-recognised and under-treated in the primary care setting. ${ }^{28,53}$ Neurogenic disorders (eg spina bifida) can cause dysfunctional voiding, which falls into the $B B D$ spectrum due to failure of relaxation of the urethral sphincter during voiding. ${ }^{53}$

\section{Diagnosis}

Evaluation of BBD is made through clinical history, physical examination, and bladder and bowel diaries. ${ }^{53}$ Tools such as the Bristol stool chart or validated screening questionnaires such as the Dysfunctional Voiding Score System and Vancouver Symptom Score can assist in diagnosis and ongoing management. ${ }^{28,52,53}$

\section{Management}

The conservative management of $\mathrm{BBD}$ consists of timed voiding, pelvic floor awareness and training, hydration, and constipation treatment or prevention. ${ }^{53}$ Approximately half of patients will improve with conservative treatment alone. ${ }^{53}$

Pharmacological management, such as anticholinergic or selective $\alpha$-blockers, if indicated for certain symptoms, may be considered.$^{53}$ It is recommended that patients refractory to conservative management be referred to a paediatrician for appropriate investigation and management of underlying anatomical or neurological abnormalities. ${ }^{53,54}$

\section{Conclusion}

Unique management challenges are posed by rUTIs in the primary care setting. Conservative measures such as hygiene, bowel and bladder education confer a significant benefit, while long-term antibiotic prophylaxis is poorly tolerated, exposes children to adverse effects and increases the likelihood of bacterial resistance.

Referral to specialist paediatric or urology services should be considered in situations where the care needs exceed the capacity of the health service, in children younger than six months of age or in cases of urosepsis or shock.

An important consideration in the management of paediatric rUTIs is the diagnosis of aberrant anatomy, VUR or BBD. Management of these patient populations follows the same progression of conservative to invasive management, and consideration must be given to the natural resolution of symptoms with age. BBD is under-recognised and under-treated despite management options being readily available in the primary care setting.

\section{Key points}

- Up to $30 \%$ of paediatric patients (aged $<6$ years) will have recurrence of UTIs.

- Children with VUR and BBD are two paediatric groups that commonly experience rUTIs.

- Successful management of rUTIs requires collaboration between the children, caretakers and healthcare professionals.

- Management of rUTIs includes conservative, alternative, antibiotics and surgical paths.

- Referral to specialist paediatric services should be considered if there are any concerns.

\section{Authors}

Clara T Petcu MD, BMedSc, Junior House Officer, Toowoomba Hospital, Qld

Emma Stehr BMBS, BN, Urology Senior House Officer, Toowoomba Hospital, Qld

James P Isaac BMedSc, University of Notre Dame, NSW

Devang Desai MBBS, MS, FRACS (Urology), Consultant Urological Surgeon, University of Queensland, Griffith University, University of Southern Queensland, Toowoomba Hospital, Toowoomba Qld

Competing interests: None.

Funding: None.

Provenance and peer review: Commissioned, externally peer reviewed.

Correspondence to:

clara.t.petcu@gmail.com

\section{References}

1. Keren R, Shaikh N, Pohl H, et al. Risk factors for recurrent urinary tract infection and renal scarring Pediatrics 2015;136(1):e13-21. doi: 10.1542/ peds.2015-0409.

2. Williams G, Craig JC. Long-term antibiotics for preventing recurrent urinary tract infection in children. Cochrane Database Syst Rev 2019;4(4):CD001534. doi: 10.1002/14651858. CD001534.pub4.

3. Stein R, Dogan HS, Hoebeke P, et al. Urinary tract infections in children: EAU/ESPU guidelines. Eur Urol 2015;67(3):546-58. doi: 10.1016/j. eururo.2014.11.007.

4. White B. Diagnosis and treatment of urinary tract infections in children. Am Fam Physician 2011;83(4):409-15.

5. Mattoo TK, Shaikh N, Nelson CP. Contemporary management of urinary tract infection in children. Pediatrics 2021;147(2):e2020012138. doi: 10.1542/ peds.2020-012138.

6. Wennerström M, Hansson S, Jodal U, Stokland E. Primary and acquired renal scarring in boys and girls with urinary tract infection. J Pediatr 2000;136(1):30-34. doi: 10.1016/s00223476(00)90045-3.

7. Shaikh N, Ewing AL, Bhatnagar S, Hoberman A. Risk of renal scarring in children with a first urinary tract infection: A systematic review. Pediatrics 2010;126(6):1084-91. doi: 10.1542/ peds.2010-0685.

8. Salo J, Ikäheimo R, Tapiainen T, Uhari M. Childhood urinary tract infections as a cause of chronic kidney disease. Pediatrics 2011;128(5):840-87. doi: 10.1542/peds.2010-3520.

9. Dason S, Dason JT, Kapoor A. Guidelines for the diagnosis and management of recurrent urinary tract infection in women. Can Urol Assoc J 2011;5(5):316-22. doi: 10.5489/cuaj.11214.

10. Desai DJ, Gilbert B, McBride CA. Paediatric urinary tract infections: Diagnosis and treatment. Aust Fam Physician 2016;45(8):558-63.

11. Shaikh N, Morone NE, Lopez J, et al. Does this child have a urinary tract infection? JAMA 2007;298(24):2895-904. doi: 10.1001/ jama.298.24.2895.

12. Foxman B. Urinary tract infection syndromes: Occurrence, recurrence, bacteriology, risk factors, and disease burden. Infect Dis Clin North Am 2014;28(1):1-13. doi: 10.1016/j.idc.2013.09.003.

13. Subcommittee on Urinary Tract Infection, Steering Committee on Quality Improvement and Management, Roberts KB. Urinary tract infection: Clinical practice guideline for the diagnosis and management of the initial UTI in febrile infants and children 2 to 24 months. Pediatrics 2011;128(3):595-610. doi: 10.1542/peds.2011-1330.

14. Queensland Emergency Care of Children Working Group. Febrile illness - Emergency management in children. South Brisbane, Qld: Children's Health Queensland Hospital and Health Service, 2019. Available at www.childrens.health.gld.gov.au/ guideline-febrile-illness-emergency-managementin-children [Accessed 1 May 2021].

15. National Institute for Health and Care Excellence. Urinary tract infection (recurrent): Antimicrobial prescribing. London, UK: NICE, 2018. Available at www.nice.org.uk/guidance/ng112 [Accessed 17 May 2021].

16. Beetz R. Mild dehydration: A risk factor of urinary tract infection? Eur J Clin Nutr 2003;57 Suppl 2:S52-58. doi: 10.1038/sj.ejcn.1601902.

17. Peters CA, Skoog SJ, Arant BS Jr, et al. Summary of the AUA guideline on management 
of primary vesicoureteral reflux in children. J Urol 2010;184(3):1134-44. doi: 10.1016/j. juro.2010.05.065

18. Korbel L, Howell M, Spencer JD. The clinical diagnosis and management of urinary tract infections in children and adolescents. Paediatr Int Child Health 2017;37(4):273-79. doi: 10.1080/20469047.2017.1382046.

19. National Institute for Health and Care Excellence. Urinary tract infection in under 16s: Diagnosis and management. London UK: NICE, 2018. Available at www.nice.org.uk/guidance/cg54 [Accessed 17 May 2021].

20. Expert Group for Antibiotic. Urinary tract infections. In: eTG complete [Internet]. West Melbourne, Vic: Therapeutic Guidelines Ltd 2021.

21. Radmayr C, Bogaert G, Dogan HS, et al. Paediatric urology guidelines. Arnhem, NL: European Association of Urology Guidelines Office, 2020.

22. The Royal Children's Hospital Melbourne. Clinical practice guidelines: Urinary tract infection. Melbourne, Vic: The Royal Children's Hospital Melbourne, 2019. Available at www.rch.org.au/ clinicalguide/guideline_index/Urinary_tract_ infection [Accessed 14 February 2021].

23. McTaggart S, Danchin M, Ditchfield M, et al; Kidney Health Australia - Caring for Australasians with Renal Impairment. KHA-CARI guideline: Diagnosis and treatment of urinary tract infection in children. Nephrology (Carlton) 2015;20(2):55-60. doi: 10.1111/nep.12349.

24. Raising Children Network. Personal hygiene for children: In pictures. East Melbourne, Vic: Raising Children Network, 2020. Available at https:// raisingchildren.net.au/toddlers/health-daily-care/ hygiene-bathing/personal-hygiene\#personalhygiene-washing-bathing-and-drying-nav-title [Accessed 1 May 2021].

25. The Royal Children's Hospital General Medicine department. Penis and foreskin care. Parkville, Vic: The Royal Children's Hospital Melbourne, 2018. Available at www.rch.org.au/kidsinfo/fact_sheets/ Penis_and_foreskin_care [Accessed 1 May 2021].

26. The Royal Children's Hospital Dermatology department. Vulval skin care for children. Parkville, Vic: The Royal Children's Hospital Melbourne, 2018. Available at www.rch.org.au/kidsinfo/fact sheets/Vulval_skin_care_for_children [Accessed 1 May 2021].

27. The Royal Children's Hospital Dermatology department. Vulval skin care for teenagers. Parkville, Vic: The Royal Children's Hospital Melbourne, 2018. Available at www.rch.org. au/kidsinfo/fact_sheets/Vulval_skin_care_for teenagers [Accessed 1 May 2021].

28. Khan A, Jhaveri R, Seed PC, Arshad M. Update on associated risk factors, diagnosis, and management of recurrent urinary tract infections in children. J Pediatric Infect Dis Soc 2019;8(2):152-59. doi: 10.1093/jpids/piy065.

29. Hosseini M, Yousefifard M, Ataei N, Oraii A, Mirzay Razaz J, Izadi A. The efficacy of probiotics in prevention of urinary tract infection in children: A systematic review and meta-analysis. J Pediatr Urol 2017;13(6):581-91. doi: 10.1016/j. jpurol.2017.08.018

30. Schwenger EM, Tejani AM, Loewen PS. Probiotics for preventing urinary tract infections in adults and children. Cochrane Database Syst Rev 2015;(12):CD008772. doi: 10.1002/14651858. CD008772.pub2

31. Jepson RG, Williams G, Craig JC. Cranberries for preventing urinary tract infections. Cochrane Database Syst Rev 2012;10(10):CD001321. doi: 10.1002/14651858.CD001321.pub5.
32. Le Saux N, Pham B, Moher D. Evaluating the benefits of antimicrobial prophylaxis to prevent urinary tract infections in children: A systematic review. CMAJ 2000;163(5):523-29.

33. Sung J, Skoog S. Surgical management of vesicoureteral reflux in children. Pediatr Nephrol 2012;27(4):551-61. doi: 10.1007/s00467-011-1933-7.

34. Hajiyev P, Burgu B. Contemporary management of vesicoureteral reflux. Eur Urol Focus 2017;3(2-3):181-88. doi: 10.1016/j. euf.2017.08.012.

35. Australian Medicines Handbook. Adelaide, SA: Australian Medicines Handbook Pty Ltd, 2020. Available at https://amhonline.amh.net.au [Accessed 17 May 2021].

36. Expert Group for Antibiotic. Prevention of urinary tract infection in children. In: eTG complete [Internet]. West Melbourne, Vic: Therapeutic Guidelines Ltd 2019.

37. Children's Health Queensland. Urinary tract infection (UTI) in children and adolescents Management and referral guideline. South Brisbane, Qld: Children's Health Queensland Hospital and Health Service, 2018. Available at www.childrens.health.qld.gov.au/referral-guidelineurinary-tract-infection [Accessed 1 May 2021].

38. Morris BJ, Wiswell TE. Circumcision and lifetime risk of urinary tract infection: A systematic review and meta-analysis. J Urol 2013;189(6):2118-24. doi: 10.1016/j.juro.2012.11.114.

39. American Academy of Pediatrics Task Force on Circumcision. Male circumcision. Pediatrics 2012;130(3):e756-85. doi: 10.1542/peds.20121990.

40. Williams G, Fletcher JT, Alexander SI, Craig JC. Vesicoureteral reflux. J Am Soc Nephrol 2008;19(5):847-62. doi: 10.1681/ ASN.2007020245.

41. Paquin AJ Jr. Ureterovesical anastomosis: The description and evaluation of a technique. J Urol 1959;82:573-83. doi: 10.1016/s00225347(17)65934-2

42. Medical versus surgical treatment of primary vesicoureteral reflux: Report of the International Reflux Study Committee. Pediatrics 1981;67(3):392-400.

43. Kessler RM, Altman DH. Real-time sonographic detection of vesicoureteral reflux in children. AJR Am J Roentgenol 1982;138(6):1033-36. doi: 10.2214/ajr.138.6.1033.

44. Ammenti A, Cataldi L, Chimenz R, et al; Italian Society of Pediatric Nephrology. Febrile urinary tract infections in young children: recommendations for the diagnosis, treatment and follow-up. Acta Paediatr 2012;101(5):451-57. doi: 10.1111/j.1651-2227.2011.02549.x.

45. Wan J, Skoog SJ, Hulbert WC, et al; Executive Committee, Section on Urology, American Academy of Pediatrics. Section on Urology response to new Guidelines for the diagnosis and management of UTI. Pediatrics 2012;129(4):e1051-53. doi: 10.1542/ peds.2011-3615

46. Arlen AM, Cooper CS. New trends in voiding cystourethrography and vesicoureteral reflux: Who, when and how? Int J Urol 2019;26(4):440-45. doi: 10.1111/iju.13915.

47. Lee LC, Lorenzo AJ, Koyle MA. The role of voiding cystourethrography in the investigation of children with urinary tract infections. Can Urol Assoc J 2016;10(5-6):210-14. doi: 10.5489/cuaj.3610.

48. Koyle MA, Elder JS, Skoog SJ, et al. Febrile urinary tract infection, vesicoureteral reflux, and renal scarring: Current controversies in approach to evaluation. Pediatr Surg Int 2011;27(4):337-46. doi: 10.1007/s00383-011-2863-y.
49. Williams G, Hodson EM, Craig JC. Interventions for primary vesicoureteric reflux. Cochrane Database Syst Rev 2019;2(2):CD001532. doi: 10.1002/14651858.CD001532.pub5

50. RIVUR Trial Investigators, Hoberman A, Greenfield SP, Mattoo TK, et al. Antimicrobial prophylaxis for children with vesicoureteral reflux. N Engl J Med 2014;370(25):2367-76. doi: 10.1056/ NEJMoa1401811.

51. Craig JC, Simpson JM, Williams GJ, et al. Prevention of Recurrent Urinary Tract Infection in Children with Vesicoureteric Reflux and Normal Renal Tracts (PRIVENT) Investigators. Antibiotic prophylaxis and recurrent urinary tract infection in children. N Engl J Med 2009;361(18):1748-59. doi: 10.1056/NEJMoa0902295

52. Shaikh N, Hoberman A, Keren R, et al. Recurrent urinary tract infections in children with bladder and bowel dysfunction. Pediatrics 2016;137(1):e20152982. doi: 10.1542/peds.2015-2982.

53. Santos JD, Lopes RI, Koyle MA. Bladder and bowel dysfunction in children: An update on the diagnosis and treatment of a common, but underdiagnosed pediatric problem. Can Urol Assoc J 2017;11(1-2 Suppl 1):S64-72. doi: 10.5489/ cuaj.4411.

54. Santos JD, Varghese A, Williams K, Koyle MA. Recommendations for the management of bladder bowel dysfunction in children. Pediat Therapeut 2014;4:1. doi: 10.4172/2161-0665.1000191. 